\title{
Instrumentation for Digitalization of Logistic Business Processes of Oil Production Organizations
}

\author{
Galiakhmetov R.A. Pushina N.N. Sokolova N.G.*

\begin{abstract}
Kalashnikov Izhevsk State Technical University, Izhevsk, Russia
\end{abstract} \\ Corresponding author. Email: sokolova-ng@mail.ru
}

\begin{abstract}
The digitalization instrumentation are used more and more widely in managing social and economic systems on the micro level, requiring the digitalization of operational business processes, aimed at the provision of managerial processes of the organization with the necessary infrastructure, data processing technologies, decision-making technologies. This paper considers the instruments of digitalization of logistic business processes in the part of forecasting expenses for oil delivery from deposits. The transportation cost value depends on the oil transportation method: motor transport and pipeline delivery is available. Actually, both transportation options are calculated in full volume at the preliminary stage of the decision making, which requires large time expenses, and additional information for calculations. In this paper, based on correlation analysis of statistical data of the oil production enterprise located in the Udmurt Republic, factors, influencing the selection of the most efficient oil transportation option, were specified, and transport cost econometric model, that will allow considerably decreasing labour expenses for calculations and analysis, was offered.
\end{abstract} Keywords: digitalization instrumentation, econometric simulation, correlation analysis, logistic business

process management, oil transportation expenses, transport cost forecast model

\section{INTRODUCTION}

Digitalization instruments are used more and more widely in management of business process, aimed at the optimization of provision, marketing and logistic, data processing technologies, decision making technologies $[1,2,3]$, that meets the Strategy of information society development in the Russian Federation for 2017-2030 [4], and the program "Digital Economy of the Russian Federation" [5]. One of directions of digitalization in pol production already became "smart wells", Internet of things, robotization of hazardous works, etc. [6]. In its turn, it created conditions for changing and optimization of various managerial business processes. This paper considers the instruments of digitalization of logistic business processes in the part of forecasting expenses for oil delivery from deposits using the example of the oil production enterprise located in the Udmurt Republic. These instruments are aimed at solutions in the field of "integrated planning and implementation", and at solutions in the sphere of logistics [7, 8]. For the time being, there exist two main options of transporting the oil produced from the deposit: either by motor transport, which requires building a highway, or via a pipeline, which requires building of this pipeline as well. The main problem here is that a decision of the transportation option selection is made at the stage of the deposit development, and after its opening, it is already impossible to change the delivery option. As the result of a wrong decision, a considerable growth of transport cost is possible, that will affect the oil production prime cost, and investment into the transport logistic will appear inefficient. In addition, the issue is worsened by the development of alternative energy sources, decrease of the share of oil products in the energy consumption structure [9]. Therefore, there exists a need for improving the oil transportation option selection instruments.

Study methods

Today, two main options are used for transportation of oil produced from the deposit: either by motor transport, or via pipeline. It this, it is considered that transportation by motor transport is beneficial in the whole if the volume of cargo shipped are low, and a pipeline is the cheapest and the most environmentally safe and sound option. Selecting the delivery method is carried out with regard of the conditions, transportation volume and type of oil products, and depends on the location of deposits, oil processing plants and oilfields, degree of development of the certain routes of communication and shipping dimensions. Main advantages and disadvantages of transportation options $[10,11,12,13]$ are given in Table 1. 
Table 1 Comparison of various oil transportation types

\begin{tabular}{|c|c|c|}
\hline $\begin{array}{c}\text { Parameters for } \\
\text { comparison }\end{array}$ & Pipeline & Motor \\
\hline Advantages & $\begin{array}{l}\text { - low pumpover cost; } \\
\text { - large transportation volumes; } \\
\text { - minimal loss of oil products; } \\
\text { - admissibility of pumpover for several oil product ranges at the } \\
\text { same time; } \\
\text { - uninterrupted supply, non-dependent on climate conditions. } \\
\text { - uninterrupted, which provides for rhythmic operation of } \\
\text { suppliers and uninterrupted provision of consumers, due to } \\
\text { which there is no more need to create large reserves of cargo } \\
\text { transported on the line ends. }\end{array}$ & $\begin{array}{l}\text { - highway network in all regions; } \\
\text { - delivery promptness and flexibility; } \\
\text { - possibility of delivery to any distances, at any time. }\end{array}$ \\
\hline \multirow[t]{2}{*}{ Disadvantages } & $\begin{array}{l}\text { - considerable initial investment; } \\
\text { - transportation route "rigidity" (impossibility to change the } \\
\text { transportation direction after the pipeline construction). }\end{array}$ & $\begin{array}{l}\text { - low transportation volume; } \\
\text { - high prime cost per product unit; } \\
\text { - dependence on climate conditions. }\end{array}$ \\
\hline & $\begin{array}{l}\text { - forest clearing or another type of the area clearing for piping, } \\
\text { clearing plants on acceptance and distribution stations; } \\
\text { - air pollution at pipe welding due to evaporation of } \\
\text { carbohydrates and equipment and mechanisms operation; } \\
\text { - water and ground pollution with carbohydrates contained in oil, } \\
\text { due to non-conformity to oil transportation technologies, } \\
\text { appearance of fissures and breaks in oil pipelines; } \\
\text { - fire and explosion breaking-outs due to oil leakages from oil } \\
\text { pipelines, pump stations, and other engineering facilities; } \\
\text { - earth moving at soil shrinkage. }\end{array}$ & $\begin{array}{l}\text { - air pollution with hazardous emissions; } \\
\text { - pollution of air, water objects and lands; } \\
\text { - change in chemical composition of soils and } \\
\text { microflora; } \\
\text { - production waste formation; } \\
\text { - heat emission to the environment at internal } \\
\text { combustion engines operation; } \\
\text { - repair is accompanied by soil pollution, accumulation } \\
\text { of metal, plastic, and rubber waste (chemical elements } \\
\text { accumulated in the soil, especially metals, are rapidly } \\
\text { absorbed by plants and transfer to the bodies of animals } \\
\text { and humans down the food chain through them); } \\
\text { - creation of the high level of noise and vibration. }\end{array}$ \\
\hline
\end{tabular}

Selecting the certain option depends of the provision of transport regularity, level of prime cost related to the location of oilfields, oil processing plants, environmental factors, and the line of the other factors. For example, all regions of our country, are covered with the highway network. However, due to the motor transport load capacity limitation, transportation prime cost appears to be very high. For this very reason, motor transportation are used only for short distances. And pipeline transport is free of these disadvantages. It is the only means of oil transportation, for which low operational expenses are typical. It can be used both for oil pumpover (oil pipelines), and for pumpover of different oil products (oil product lines), but requires considerable investment expenses. In the whole, there are various methods of comparing these transportation options, but the assessment in terms of economic efficiency prevails [14]. At this, the general conclusion is that motor transport is characterized by high operational expenses and low volume of capital expenses. On the contrary, pipeline transport, has the lowest pumpover prime cost and large simultaneous capital investment into the pipeline construction at fast return of expenses provided that oil production volumes are large.

Further, we will consider the oil transportation option selection algorithm in JSC "Belkamneft", oil deposits of which are located in the Udmurt Republic. When putting a new deposit into operation, with the purpose of obtaining the comprehensive economic assessment of selecting the oil transportation at the enterprise, the complete analysis is carried out, including geological (potential volumes of production from a new oil deposit), technology (technologies of new deposit drilling and improvement) and economic (expense and income simulation with regard of the transportation option) factors. The oil transportation option selection algorithm contains five parts:

1. In the crude oil unit, the forecast of stock is made based on the existing data about the initial site gross life.

2. In the geological and oilfield unit, deposit development is simulated on the condition of maximal increase of carbohydrates production volume in the conditions of limited raw materials source, placement of output wells, forecasted initial flow rate and forecast of its decrease.

When forecasting volumes of carbohydrates production, a model is used that includes the stage of the increasing production of carbohydrates, stable production stage and production decline stage. The maximal level of production of the "shelf" is 4-6\% from the initial reserve amount for oil. The increasing production period is 3-5 years, the "shelf" is kept for approximately $4-7$ years, and the average site development time is $25-35$ years.

3 . The forecast of capital and operational expenses for the development of a new oil deposit is made in the technical and economic unit. The following sections are classified: capital investment and operational expenses. Each section also includes expenses for the transport component. At this, expenses under the two oil transportation options are calculated, and the final choice preference of the certain means of transportation is done under the principle "minimal expenses" and depending on the minimal payback time.

In the Section "Capital investment", there is provided the assessment of cost of all the required preliminary work, including the assessment of expenses for output infrastructure, for transport infrastructure, for exploration work conduct, for output wells drilling. The oil 
suggested to make this choice at the second stage with regard of the correlation analysis, that will allow selecting factors, influencing at transportation expenses, and also based on the econometric simulation of expenses, that will considerably decrease the labour expenses for the further calculations.

\section{RESEARCH RESULTS}

In terms of developing an econometric model, an information base was formed. Total 21 deposits (Table 2), using motor transport, was analyzed, but finally, only 10 deposits were left for the analysis (Table 3), for which transportation is carried out by the own motor transport. Concerning transportation by motor transport, the main study hypothesis is that the volume of transportation expenses is influenced by the following factors: well flow rate, transportation volume, distance, fuel price. calculated in full volume, starting from the second stage, and the final decision is made on the fifth stage. It is

Table 2 Initial data by deposits for oil transportation by motor transport [15]

\begin{tabular}{|c|c|c|c|c|c|}
\hline Route & $\begin{array}{c}\text { Flow rate, } \\
\text { t/day }\end{array}$ & $\begin{array}{c}\text { Transportation } \\
\text { volume, m3/day }\end{array}$ & Distance, $\mathbf{k m}$ & Fuel price, RUB & $\begin{array}{l}\text { Transport costs, } \\
\text { RUB per day }\end{array}$ \\
\hline Oblastnovo - CPF Yuski & 49 & 79.57 & 95 & 42 & 25624.59 \\
\hline Reshetnikovo - CPF Yuski & 88 & 518.79 & 119 & 42 & 213607.33 \\
\hline Dintemsk - CPF Buranovo & 10 & 28.37 & 14 & 42 & 15680.36 \\
\hline Ityn - CPF Smolniki & 15 & 6.63 & 53 & 42 & 2938.90 \\
\hline Irym - CPF Smolniki & 1 & 56.00 & 14 & 42 & 15608.68 \\
\hline Debes - CPF Smolniki & 7 & 135.09 & 36 & 42 & 52864.65 \\
\hline Shadbegov - CPF Smolniki & 5 & 8.64 & 33 & 42 & 3960.82 \\
\hline Pibanshur - CPF Smolniki & 6 & 10.76 & 50 & 42 & 6281.60 \\
\hline Pyzep - CPF Smolniki & 3 & 5.85 & 147 & 42 & 6961.52 \\
\hline Kuligin - CPF Smolniki & 3 & 3.84 & 118 & 42 & 3997.66 \\
\hline Turetzk - CPF Smolniki & 30 & 30.15 & 110 & 42 & 22482.29 \\
\hline Zolotaryov - CPF Smolniki & 21 & 41.02 & 201 & 42 & 78586.70 \\
\hline Bygyn well 427 - CPF Chernovsk & 5 & 26.01 & 38 & 42 & 9814.98 \\
\hline Tylovay- CPF Chernovsk & 7 & 19.86 & 55 & 42 & 10976.25 \\
\hline Korobov - DP "Oshvortsy" & 19 & 63.32 & 56 & 42 & 19184.42 \\
\hline Pionersk - CPF Smolniki & 3 & 4.78 & 77 & 42 & 3294.70 \\
\hline $\begin{array}{l}\text { DP "Yak. Bodya" - DP } \\
\text { "Oshvortsy" }\end{array}$ & 228 & 180.83 & 21 & 42 & 20885.88 \\
\hline $\begin{array}{c}\text { CPF Buranovo - PCS Malaya } \\
\text { Purga }\end{array}$ & 222 & 429.93 & 23 & 42 & 37675.14 \\
\hline $\begin{array}{c}\text { CPF Zabegalovo - PCS Malaya } \\
\text { Purga }\end{array}$ & 215 & 248.55 & 74 & 42 & 57936.53 \\
\hline Pokrovsk - CPF Yuski & 20 & 9.42 & 142 & 42 & 4573.00 \\
\hline CPF Polom - CPF Smolniki & 109 & 31.02 & 71 & 42 & 11760.61 \\
\hline Correlation factor & 0.2615 & 0.7808 & 0.2960 & - & \\
\hline
\end{tabular}


Table 3 Initial data by deposits for oil transportation by own motor transport

\begin{tabular}{|c|c|c|c|c|c|}
\hline Route & $\begin{array}{c}\text { Flow rate, } \\
\text { t/day }\end{array}$ & $\begin{array}{c}\text { Transportatio } \\
\mathbf{n} \text { volume, } \\
\mathbf{m} \mathbf{3} / \mathbf{d a y}\end{array}$ & Distance, $\mathbf{k m}$ & $\begin{array}{c}\text { Fuel price } \\
\text { Transport } \\
\text { costs, RUB } \\
\mathbf{p e r} \text { day }\end{array}$ \\
\hline Dintemsk - CPF Buranovo & 10 & 28.37 & 14 & 42 & 15680.36 \\
\hline Ityn - CPF Smolniki & 15 & 6.63 & 53 & 42 & 2938.90 \\
\hline Irym - CPF Smolniki & 1 & 56.00 & 14 & 42 & 15608.68 \\
\hline Shadbegov - CPF Smolniki & 5 & 8.64 & 33 & 42 & 3960.82 \\
\hline Pibanshur - CPF Smolniki & 6 & 10.76 & 50 & 42 & 6281.60 \\
\hline Pyzep - CPF Smolniki & 3 & 5.85 & 147 & 42 & 6961.52 \\
\hline Kuligin - CPF Smolniki & 3 & 3.84 & 118 & 42 & 3997.66 \\
\hline Turetzk - CPF Smolniki & 30 & 30.15 & 110 & 42 & 22482.29 \\
\hline Bygyn well 427 - CPF Chernovsk & 5 & 26.01 & 38 & 42 & 9814.98 \\
\hline Tylovay- CPF Chernovsk & 7 & 19.86 & 55 & 42 & 10976.25 \\
\hline Pionersk - CPF Smolniki & 3 & 4.78 & 77 & 42 & 3294.70 \\
\hline
\end{tabular}

Correlation analysis demonstrated that the most considerable impact on the level of expenses is caused by the transportation volume factors (correlation factor 0.7808 , strong direct dependence), and the least, well flow rate (correlation factor 0.2615). Model of expenses level dependence on various factors has the following form (formula (1)):

$3 \mathrm{a}=331,25 \times \mathrm{X} 1+338,52 \times \mathrm{X} 2+33,44 \times \mathrm{X} 3-$

$40,84 \times \mathrm{X} 4$

where $3 \mathrm{a}-$ expenses for oil transportation by motor transport, RUB/day;

$\mathrm{X} 1$ - flow rate, $\mathrm{t} /$ day;

$\mathrm{X} 2$ - transportation volume, $\mathrm{m} 3 /$ day;

$\mathrm{X} 3$ - distance, $\mathrm{km}$;

X4 - fuel price, RUB

For the example, if transportation distance increases by 1 $\mathrm{km}$, then current expenses grow by $33.44 \mathrm{RUB}$, and transportation volume change by $1 \mathrm{~m} 3$ will cause the motor transport expenses by 338.52 RUB. Model determinacy factor is 0.97 , that proves high correlation.

Concerning transportation by pipeline, the main study hypothesis is that the volume of transportation expenses (they are actually called current expenses for the pipeline servicing) is influenced by the following factors: well flow rate, length, rated capacity, pipe diameter, pipe wall thickness, amount of investment, distance, etc. Total 20 deposits (Table 4), using the pipeline oil transportation, were analyzed.

Correlation analysis demonstrated that the most considerable impact on the level of expenses is caused by length (correlation factor 0.91, strong direct dependence), and the least, rated capacity (correlation factor 0.05). Model of expenses level dependence on various factors has the following form (formula (2)):

$3 \mathrm{~T}=-2,9 \times \mathrm{X} 1+413 \times \mathrm{X} 2+0,4 \times \mathrm{X} 3-12 \times \mathrm{X} 4+$

$2007,7 \times X 5+14 \times$ X6

where $3 \mathrm{~T}-$ expenses for oil transportation via the pipeline, $\mathrm{RUB} /$ day;

$\mathrm{X} 1$ - flow rate, $\mathrm{t} /$ day;

$\mathrm{X} 2$ - length, km;

$\mathrm{X} 3$ - rated capacity, m3/day;

$\mathrm{X} 4$ - pipe diameter, $\mathrm{mm}$;

X5 - wall thickness, mm;

X6 - investment into construction, mln RUB

That is, if the pipeline length increases by $1 \mathrm{~km}$, current costs will grow by 413.13 RUB, growth of investment into building by1 mln RUB will cause the increase of current expenses for pipeline transport by 14.34 RUB The determinacy factor of 0.99 is of high value, differences between actual expenses and calculated " $\mathrm{Y}$ " values are reduced 
Table 4 Initial data by deposits for oil transportation by pipeline transport [16]

\begin{tabular}{|c|c|c|c|c|c|c|c|}
\hline Route & $\begin{array}{c}\text { Current } \\
\text { expenses for } \\
\text { servicing } \\
\text {, RUB/day. }\end{array}$ & $\begin{array}{c}\text { Flow rate } \\
\text { t/day }\end{array}$ & $\begin{array}{l}\text { Length } \\
\text { km }\end{array}$ & $\begin{array}{l}\text { Rated } \\
\text { power, } \\
\text { m3/day }\end{array}$ & $\begin{array}{c}\text { Pipe } \\
\text { diameter, } \\
\text { mm }\end{array}$ & $\begin{array}{c}\text { Wall } \\
\text { thickness, } \\
\text { mm }\end{array}$ & $\begin{array}{c}\text { Investment } \\
\text { into } \\
\text { construction, } \\
\text { mln RUB }\end{array}$ \\
\hline $\begin{array}{c}\text { Zabegalovo - CPF } \\
\text { "Zabegalovo" }\end{array}$ & 15461.74 & 215 & 4.274 & 1100 & 159 & 7 & 10.70 \\
\hline $\begin{array}{c}\text { Pokrovsk - CPF } \\
\text { Yuski }\end{array}$ & 15440.60 & 20 & 3.631 & 1500 & 159 & 7 & 9.80 \\
\hline $\begin{array}{c}\text { V-Postol - CPF } \\
\text { Yuski }\end{array}$ & 18268.55 & 275 & 8.000 & 1500 & 159 & 8 & 21.60 \\
\hline $\begin{array}{c}\text { Yuski - CPF } \\
\text { Yuski }\end{array}$ & 16808.96 & 792 & 4.428 & 8200 & 219 & 8 & 29.00 \\
\hline $\begin{array}{c}\text { Buranovo - CPF } \\
\text { Buranovo }\end{array}$ & 22541.71 & 123 & 14.000 & 1100 & 159 & 8 & 35.00 \\
\hline $\begin{array}{c}\text { Smolnikov - CPF } \\
\text { Smolniki } \\
\end{array}$ & 11409.81 & 175 & 3.500 & 1100 & 159 & 7 & 8.70 \\
\hline $\begin{array}{l}\text { Debes - CPF } \\
\text { Smolniki } \\
\end{array}$ & 21317.91 & 77 & 17.600 & 1000 & 159 & 8 & 44.00 \\
\hline $\begin{array}{c}\text { Polom - CPF } \\
\text { Polom }\end{array}$ & 15561.22 & 58 & 7.300 & 1100 & 114 & 7 & 16.70 \\
\hline $\begin{array}{l}\text { Sosnovsk - CPF } \\
\text { Chernovsk }\end{array}$ & 25441.50 & 285 & 25.000 & 1500 & 219 & 8 & 62.50 \\
\hline $\begin{array}{c}\text { Chernovsk -CPF } \\
\text { Chernovsk }\end{array}$ & 12653.34 & 669 & 0.500 & 1500 & 219 & 8 & 1.30 \\
\hline $\begin{array}{c}\text { Bygin - CPF } \\
\text { Chernovsk }\end{array}$ & 22757.18 & 293 & 25.000 & 1500 & 219 & 8 & 60.00 \\
\hline $\begin{array}{c}\text { Tzentralny - CPF } \\
\text { Chernovsk } \\
\end{array}$ & 24194.68 & 725 & 27.900 & 1500 & 219 & 8 & 68.00 \\
\hline $\begin{array}{l}\text { Yuzhno-Listvensk } \\
\text { - CPF Chernovsk }\end{array}$ & 12656.63 & 237 & 0.600 & 1100 & 159 & 7 & 1.40 \\
\hline $\begin{array}{c}\text { Patraki - DP } \\
\text { Patraki }\end{array}$ & 16952.04 & 309 & 8.780 & 1400 & 219 & 8 & 52.00 \\
\hline $\begin{array}{l}\text { Out. Dmitriev - } \\
\text { CPF Chernovsk }\end{array}$ & 25392.18 & 50 & 23.500 & 1100 & 219 & 8 & 63.40 \\
\hline $\begin{array}{l}\text { Yuski d. pad } 4 \text { - } \\
\text { pad } 2\end{array}$ & 11332.38 & 706 & 1.145 & 1000 & 114 & 6 & 2.60 \\
\hline $\begin{array}{l}\text { Well1904P - pad } \\
1 \text { of Zolotarev d. }\end{array}$ & 11385.41 & 10 & 2,758 & 880 & 114 & 6 & 7,70 \\
\hline $\begin{array}{l}\text { Well27 - pad } 2 \text { of } \\
\text { Sosnovo d. }\end{array}$ & 12709.23 & 136 & 2.200 & 880 & 89 & 6 & 6.10 \\
\hline $\begin{array}{l}\text { CPF Chernovsk - } \\
\text { t. temp. Main line }\end{array}$ & 10202.15 & 2803 & 7.591 & 1600 & 219 & 8 & 63.25 \\
\hline $\begin{array}{l}\text { System of oil } \\
\text { collection from } \\
\text { Chernov d. }\end{array}$ & 11414.54 & 669 & 3.644 & 1100 & 159 & 8 & 10.12 \\
\hline Correlation factor & - & -0.32 & 0,91 & 0.05 & 0.48 & 0.56 & 0.73 \\
\hline
\end{tabular}


Table 5 Impact of parameters on investment into the pipeline construction

\begin{tabular}{|c|c|c|c|c|c|c|}
\hline Route & $\begin{array}{l}\text { Flow } \\
\text { rate, } \\
\text { t/day }\end{array}$ & Length, km & $\begin{array}{l}\text { Rated power, } \\
\text { m3/day }\end{array}$ & $\begin{array}{c}\text { Tube } \\
\text { diameter, } \\
\text { mm }\end{array}$ & $\begin{array}{c}\text { Wall } \\
\text { thickness, } \\
\text { mm }\end{array}$ & $\begin{array}{c}\text { Investment into } \\
\text { construction, } \\
\text { mln RUB }\end{array}$ \\
\hline Zabegalovo - CPF "Zabegalovo" & 215 & 4.274 & 1100 & 159 & 7 & 10.70 \\
\hline Pokrovsk - CPF Yuski & 20 & 3.631 & 1500 & 159 & 7 & 9.80 \\
\hline V-Postol - CPF Yuski & 275 & 8.000 & 1500 & 159 & 8 & 21.60 \\
\hline Yuski - CPF Yuski & 792 & 4.428 & 8200 & 219 & 8 & 29.00 \\
\hline Buranovo - CPF Buranovo & 123 & 14.000 & 1100 & 159 & 8 & 35.00 \\
\hline Smolnikov - CPF Smolniki & 175 & 3.500 & 1100 & 159 & 7 & 8.70 \\
\hline Debes - CPF Smolniki & 77 & 17.600 & 1000 & 159 & 8 & 44.00 \\
\hline Polom - CPF Polom & 58 & 7.300 & 1100 & 114 & 7 & 16.70 \\
\hline Sosnovsk - CPF Chernovsk & 285 & 25.000 & 1500 & 219 & 8 & 62.50 \\
\hline Chernovsk -CPF Chernovsk & 669 & 0.500 & 1500 & 219 & 8 & 1.30 \\
\hline Bygin - CPF Chernovsk & 293 & 25.000 & 1500 & 219 & 8 & 60.00 \\
\hline Tzentralny - CPF Chernovsk & 725 & 27.900 & 1500 & 219 & 8 & 68.00 \\
\hline Yuzhno-Listvensk - CPF Chernovsk & 237 & 0.600 & 1100 & 159 & 7 & 1.40 \\
\hline Patraki - DP Patraki & 309 & 8.780 & 1400 & 219 & 8 & 52.00 \\
\hline Well27 - pad 2 of Sosnovo d. & 136 & 2.200 & 880 & 89 & 6 & 6.10 \\
\hline Out. Dmitriev - CPF Chernovsk & 50 & 23.500 & 1100 & 219 & 8 & 63.40 \\
\hline Yuski d. pad 4 - pad 2 & 706 & 1.145 & 1000 & 114 & 6 & 2.60 \\
\hline Well1904P - pad 1 of Zolotarev d. & 10 & 2,758 & 880 & 114 & 6 & 7,70 \\
\hline CPF Chernovsk - t. temp. Main line & 2803 & 7.591 & 1600 & 219 & 8 & 63.25 \\
\hline $\begin{array}{l}\text { System of oil collection from Chernov } \\
\text { d. }\end{array}$ & 669 & 3.644 & 1100 & 159 & 6 & 10.12 \\
\hline Correlation factor & 0.30 & 0.87 & 0.08 & 0.71 & 0.71 & - \\
\hline
\end{tabular}

But the feature of the model received is that current expenses for oil transportation via the pipeline depend on the investment volume, and their planning at the stage of transportation option selection is complicated, so the need of building the econometric model appeared in this case as well. For this purpose, it is required to determine the factors influencing on the amount of investment made: well flow rate, length, rated capacity, pipe diameter, pipe wall thickness, Initial data are given in Table 5.

As it was expected, the most considerable impact on the amount of investment is caused by the pipeline length (correlation factor 0.87 , that proves high connection, strong direct dependence), and the least, rated capacity (correlation factor 0.08).

The model obtained has the following form (3):

И $=0,01 \times \mathrm{X} 1+2,32 \times \mathrm{X} 2+0,07 \times \mathrm{X} 4-1,55 \times$

$\mathrm{X} 5(3)$

where И - amount of investment, mln RUB;

$\mathrm{X} 1$ - flow rate, t/day;

$\mathrm{X} 2$ - length, km;

$\mathrm{X} 4$ - pipe diameter, $\mathrm{mm}$;
X5 - wall thickness, mm.

That is, if the pipeline length increases by $1 \mathrm{~km}$, investment costs will grow by $2.32 \mathrm{mln}$ RUB Rated capacity has almost zero impact on the amount of investment, so it is absent in the formula. Model determinacy factor is 0.96 , that proves high correlation. Discussion of the study results and checking the models We will check the models obtained by the example of two developed deposits, Tylovay and CPF Buranovo. Tylovay deposit is located at the distance of $55 \mathrm{~km}$ from "Chernovsk" crude processing facility, well flow rate -7 t/day. From CPF Buranovo, oil is transported to the distance of $23 \mathrm{~km}$ to the transfer point in Malaya Purga village, flow rate - 222 tons per day. Today, transportation under both deposits is carried out by motor transport (see Table 2).

First, we will use the formula (3) to calculate the investment volume by two deposits. At this, we set the pipeline length in calculations to the distance of oil transportation by fuel trucks. As the result, the amount of 


\section{REFERENCES}

will be:

$\mathrm{I}_{\text {Tylovay }}=0,01^{\times} 7+2,32^{\times} 55+0,07^{\times} 159-1,55^{\times} 6=129,5 \mathrm{mln}$

RUB.

$\mathrm{I}_{\text {Buranovo }}=0,01^{\times} 215+2,32^{\times} 23+0,07^{\times} 159-1,55^{\times} 8=54,2$

mln RUB

Then, we will use the formula (2) in order to calculate possible expenses for oil transportation from these deposits by pipeline transport:

$\mathrm{E}_{\text {Tylovay }}=-2,9^{\times} 7+413^{\times} 55+0,4^{\times} 880-$

$12^{\times} 159+2007,7^{\times} 6+14^{\times} 129,5=34997,9 \mathrm{RUB} /$ day

$\mathrm{E}_{\text {Buranovo }}=-2,9^{\times} 215+413^{\times} 23+0,4^{\times} 1500$ -

$12^{\times} 219+2007,7^{\times} 8+14^{\times} 54,2=23067,9 \mathrm{RUB} /$ day

Let us compare the obtained expenses expenses for oil transportation via the pipeline with current expenses for oil transportation from these deposits by fuel trucks (see Table 2). The company spends 10976.25 RUB per day for oil transportation by motor transport from Tylovay deposit to CPF Chernovsk. And at pipeline laying, cost may rise up to 35 ths. RUB per day. It was also found out in the process of the locality map investigation that the planned route has a natural obstacle in its way represented by a pond, that will actually increase the investment expenses for the pipeline construction. Therefore, the oil pipeline construction to this deposit is not beneficial for the company because it is located at a considerable distance from the processing station, the oil flow rate is low, and the supposed pipeline route comes through the pond.

Oil transportation from CPF Buranovo to PCS Malaya Purga by motor transport costs 37675.14 RUB per day for Belkamneft. However, according to the forecast made, at the pipeline construction, current expenses will reduce to 23067.9 RUB per day. Therefore, it is more beneficial for the enterprise to run the pipeline to this deposit, however, taking into account the investment for pipeline construction, the payback time of which will be approximately 10 years.

In conclusion, it should be noted that the main factors influencing the selection of oil transportation option are the deposit flow rate and its remoteness, so the development of a two-factor model is possible.

\section{CONCLUSION}

For the time being, improvement of various business processes is considered important. This paper offers the instruments of digitalization of logistic business processes in the part of forecasting expenses for oil transportation from deposits. Actually, the instruments offered represent an econometric model for forecasting the value of oil delivery transport expenses. Such factors as well flow rate, its remoteness, fuel prices, possible pipeline characteristics are characterized as the main operation factors. The models obtained have a high degree of reliability and can be used in practice.
[1] What is digital transformation? // Economics of innovation: RBC project. [Electronic resource]. URL: https://www.rbc.ru/trends/innovation/5d695a969a79476 ed81148ef (am3essed 02.03.2020)

[2] V.G. Khalin, G.V. Chernova, Digitalization and its impact on the Russian economy and society: advantages, challenges, threats and risks, Mgmt. Consulting, 10 (2018) 46-63. - DOI10.22394/17261139-2018-10-46-63

[3] N.G. Sokolova, O.V. Titova, Digital marketing as a type: concept, tools and effects, Advances in Economics, Business and Management Research, volume 81 1st International Scientific Conference "Modern Management Trends and the Digital Economy: from Regional Development to Global Economic Growth" (MTDE 2019) , pp.509-513. DOI: $10.2991 /$ mtde-19.2019.101, ISBN: 9789462527218.

[4] The development strategy of the information society in the Russian Federation for 2017-2030. Approved By the Decree of the President of the Russian Federation of May 9, 2017 No. 203 [Electronic resource].

URL:

http://docs.cntd.ru/document/420397755.

[5] Program "Digital Economy of the Russian Federation" Approved. by order of the Government of the Russian Federation of July 28, 2017 N1632-r [Electronic resource]. http://static.government.ru/media/files/9gFM4FHj4PsB 79I5-v7yLVuPgu4bvR7M0.pdf

[6] Digital oil production: tuning for the industry. VYGON Consulting. 2018.June. S.9. [Electronic resource].

https://vygon.consulting/upload/iblock/d11/vygon_cons ulting_digital_upstream.pdf

[7] Digital transformation of the oil and gas industry: a popular myth or objective reality? OIL AND GAS. Joint informational and analytical publication. S. 11 [Electronic resource]. URL: http://oilandgasforum.ru/data/files/Digest\%20site/DAI DJEST\%20WEB2.pdf (am3essed 12.03.2020)

[8] O. A. Romanova, Priorities of the industrial policy of Russia in the context of the challenges of the fourth industrial revolution. Part 1, Economy of the region, 14(2) (2018) 425. 
[9] L. V. Eder, I. V. Filimonova, V. Yu. Nemov, I. V. Agile, Forecasting energy and oil consumption by road in the regions of the Russian Federation , Reg. Econ., 13(3) (2017) 861.

[10] Methods of oil transportation and their features. [Electronic resource]. https://neftok.ru/transportirovka

[11] Rosprirodnadzor: up to 10 thousand tons of oil gets into the environment. And so every year. [Electronic resource] - https://neftegaz.ru/news/view/149112Rosprirodnadzor-V-okruzhayuschuyu-sredu-popadaetdo-10-tys-t-nefti.-I-tak-kazhdyj-god.

[12] Environmental problems of the oil industry: safety conditions. [Electronic resource] http://pue8.ru/ekologiya/255-ekologicheskie-problemyneftyanoj-promyshlennosti.html.

[13] Aliev R.A. Pipeline transport of oil and gas. Ripol Classic, 2013, 364 p.

[14] Annual Report of PJSC Belkamneft for 2015-2018. 